\title{
Land Evaluation and Soil Erodibility in Relation to Their Properties of Some Soils in Northwest Nile Delta
}

\author{
R. I. Fayed \\ Soil Salinity Lab. Alex., Soil, water and Environ. Res. Inst., Agric. Res. Center-Egypt \\ Corresponding author: R. I. Fayed, e-mail: ragab.fayed@yahoo.com
}

\begin{abstract}
The current research aims to investigate soil characteristics, estimate the soil erodibility factor $(\mathrm{K})$ and define the important soil properties affecting erodibility, wind erosivity factor $(C)$, rainfall erosivity factor $(R)$ and to find out the land capability and soil suitability classification in Abis region at south Mariut Lake. Representative forty one soil profiles were chosen to represent lacustrine soils at Abis region. The results indicated that the soils were developed in the lacustrine deposits of Lake Mariut and characterized by sandy loam to sandy clay loam texture in most profiles. The EC values ranged between 0.77 and $10.91 \mathrm{dS} / \mathrm{m}$, ESP values being in the range of 1.73 to 18.26, total carbonate content ranged between 2.0 and $34.0 \%, \mathrm{pH}$ values ranged between 7.51 and 8.83 at the surface layers. In the subsurface layers the corresponding values 0.83 and $13.86 \mathrm{dS} / \mathrm{m}$ for EC, 1.02 to 36.32 for ESP, 1.0 and $46.0 \%$ for total carbonate, 7.66 and 8.46 for $\mathrm{pH}$. The result also, shows that the water table depth ranged from 25 to $120 \mathrm{~cm}$. The $\mathrm{EC}_{\mathrm{w}}$ and SAR of water table vary from 1.19 to $35.80 \mathrm{dS} / \mathrm{m}$ and from 3.16 to 47.18 , respectively.

The values of soil erodibility factors "K" ranged between $0.088-0.112$ for the studied area. Most of the studied profiles belong to class 2 which represent soils that are moderate erodible, while some of the studied profiles belong to class 1 which represent soils that non erodible. The K- values are positively correlated with \%silt $(r=0.68), \%$ very fine sand $(r=0.48)$ and $\%$ sand $(r=0.33)$. In contrast they are negatively correlated with $\% \mathrm{CaCO}_{3}(r=0.21)$, \%organic matter $(r=0.31)$ and \%clay $(r=0.51)$. The total value of Rainfall erosivity factor $(R)$ is low (41.0) due to the relative dry climate, while wind erosivity factor (C) ranged between 3.33 and 18.28. The annual value of $\mathrm{C}$ was 134.5 and this relatively high value may be attributed to increasing of wind velocity in this area. With regard to Land capability, most of the study area was classified as class 2 (C2), while limited areas belong to class 3 (C3) which reflects fair or moderate capability with available water, hydraulic conductivity, soil depth and soil salinity as limiting factor. With respect to soil suitability, most soils were suitable (class 2 ) for the tested crops, while some soils were highly suitable (class 1 ) and limited soils belong to class 3 or class 4 which reflect moderate or marginal degree of soil suitability for some of the traditional tested crops. Regarding the sub classes, main limiting soil properties in most of the studied soils are available water, hydraulic conductivity, soil depth, salinity and exchangeable sodium percent.
\end{abstract}

Keywords: Abis area, soil characteristics, Soil Erodibility, Wind Erosivity, Rainfall Erosivity, Land evaluation

\section{INTRUDUCTION}

Agriculture expansion in Egypt especially in sandy and saline soils at northern lakes depends mainly on irrigation. Land management is useful for improving soil characteristics, and achieving the agriculture sustainability. Therefore, better soil management and conservation are essential to improve soil production and reduce soil degradation.

Many studies have been carried out to characterize lacustrine soils, among them, Labib and Sys (1970), El-Husseiny et al. (1988) and Fayed (2011). They pointed out that lacustrine soils are salt- affected, stratified, poorly drained to water logged, heavy to light textured, poor in organic matter and $\mathrm{CaCO}_{3}$, percent and underlain by shelly lagoonal or lake deposits.

The morphological characteristic of the lacustrine soils located south of Lake Maruit were studied by Morgan (1976), Darwish (1977), El-Husseiny et al. (1985), El-Attar et al. (1987), El-Zahaby et al (1999) and Fayed and El- 
Menshawy (2006). They found that these soils are stratified and salt affected in some locations. Shells are abundant but irregularly distributed in both the vertical and horizontal direction. The texture ranges from silty clay to clay loam. The pedognic processes include the aggregation, salinization, alkalization, and gleyzation in addition to the phenomena of slickensides.

The chemical properties of the deposits located south of Lake Maruit were studied by many authors. El-Attar and Bakr (1963), Mahmoud (1978) and El-Zahaby et al. (1999) reported that the high $\mathrm{CaCO}_{3}$ content of these soils may be attributed to the frequent occurrence of shells, while the high content of soluble $\mathrm{Na}^{+}, \mathrm{Ca}^{++}, \mathrm{Cl}^{-}$and $\mathrm{SO}_{4}^{--}$is due to the saline nature of their parent material. In another study, El-Husseiny et al. (1985) compared the chemical properties of some soils in the lacustrine deposits of Lake Maruit and found that the northern soils (at Abis) are moderate to non saline-affected as a result of leaching by irrigation and perfect drainage, while the southern soils (at trouga) are saline alkali with a surface crust formed by the upward movement of salts. They also reported that the total carbonate of these soils is low to moderate $(1.0-11.6 \%)$ but greatly increase with depth in the layer of shell accumulations (28-35\%). El-Attar et al. (1987) studied the soils of El-Nahda project, which are developed on calcareous lacustrine deposits. They found that these soils are characterized by secondary salt accumulations due to the capillary mechanism of soluble salts under the conditions of the dry hot climate, the presence of clay layers and the shallow saline ground water.

A soil inherent erodibility, which is a major factor of erosion prediction and land-use planning, is a complex property depends on its infiltration capacity, and its capacity to resist detachment and transport by rainfall and runoff. Soil erosion is the greatest hazard to the long-term maintenance of soil fertility in most environments. It reduces soil depth and causes loss of topsoil that has most nutrients, most organic matter and the best structure for root growth. Moreover, erosion can reduce crop yields (Wild, 1996).

Erosion and sedimentation are land resource problems that lead to significant economic, environmental, and social impacts (Morgan, 1996).Soil erosion involves the detachment of sediment and soil from the soil surface by raindrop impact, flowing water and winds (Bahr and Vogtle, 1999; Nikkami et al., 2002; El-Hassanin et al. 2002 and Gomez et al., 2004). Egypt as located in semi-arid region suffers from this problem. The rate of erosion depends on erosive forces of rainfall and runoff (erosivity) and susceptibility of the soil for detachment by these factors (erodibility). Accurate information on soil erodibility is important for soil erosion prediction and control, as well as, for planning of modern farming techniques. Soil erodibility factor $(K)$ represents both susceptibility of soil for erosion and the rate of runoff. Many attempts have been made to devise a simple index for erodibility based either on the properties of soil or on its response to rainfall and winds. Wischmeier and Mannering (1969) showed that soils high in silt and low in clay and organic matter are the most erodible.

Wischmeier et al. (1971) indicated that the organic matter content reduces erodibility because it reduces the susceptibility of the soil to detachment, and it increases infiltration, which reduce runoff and thus erosion. Also, they revealed that $(K)$ could be estimated if the grain size distribution, organic content, structure index, and permeability of the soil are known. 
Romkens et al. (1977) indicated that erodibility factor $(\mathrm{K})$ could be predicted by some soil properties [(Silt + v. f. s) x (silt + sand)], organic carbon, permeability, and soil structure. Beasley et al. (1984) showed that, the flow of water causes the movement of minerals, plant nutrients, soil particles, and other organic and inorganic pollutants. Kukal et al. (1991) found that erodibility of some Indian soils was strongly correlated $(r=0.98)$ with amounts of (silt $+v$. f. s). Bahnassy (1992) estimated soil loss for wadi El-Haraka, North Western Coast, Egypt, and found that it varied from 4 to $25 \mathrm{t} / \mathrm{ha} / \mathrm{yr}$. In Egypt, limited data are available for the surface runoff, soil erodibility and erosivity, as will as, field practices which control soil erosion.

Land evaluation has been defined as the process of assessing or predicting the performance of land for specific purposes (FAO, 1976). Soil attributes needed in land evaluation may be obtained from soil databases and are typically used alone or in conjunction with other land characteristics to derive the distribution of land suitability, limitations or potential ratings for various land use types. The land evaluation could be performed using soil interpretative groupings, productivity ratings or crop growth models.

Many investigators suggested that land evaluation should be made according to most of the following parameters: soil texture, salinity, exchangeable sodium percentage, $\mathrm{pH}, \mathrm{CaCO}_{3}$, organic matter, level of water table, salinity of water table, profile depth and necessity of drainage (Omar and El-Kholie, 1970; El-Nahal et al., 1977; Mansour, 1979; El-Menshawy et al., 2005 and Abd El-Rahman et al., 2009). El-Fayoumy (1989) modified a system to include soil fertility and irrigation water factors in addition to soil properties. Each of the above mentioned factors was described as an index value to give its status as a percentage. These indices were calculated using empirical equations. In general, all land evaluation systems are very similar in the concept, although there are some differences between them in the parameters, which they are based on.

Agricultural Land Evaluation System for arid region (ALES-Arid) is a new approach for land capability and suitability evaluation. The calculation of capability index by ALES-Arid is an indication of land capability according to multiplication method (Abdel Kawy et al., 2004). ALES-Arid evaluates the suitability for different crops (field crops, vegetables, forage crops, and fruit tress) to identify the optimum land use. Land suitability classes were identified using the matching between standard crop requirements (FAO, 1985; Sys and Verheye, 1974; and Sys et al., 1993) and actual land characteristics.

The objectives of the this work are to study and discuss soil characterization, assessment the soil erodibility factor $(K)$ and define the important soil properties affecting erodibility, wind erosivity factor $(\mathrm{C})$, rainfall erosivity factor (R) and to find out the land capability and soil suitability classification using reliable soil qualities to be helpful in better soil management and land use in the lacustrine soils of Abis region at south Mariut Lake since a very limited work was reported for this area. 


\section{MATERIALS AND METHODS}

\section{Study area:}

The studied area is located at the North Western part of the Nile Delta, which represent soils developed from lacustrine deposits at Abis region south of Mariut Lake. It is located approximately between Latitudes $31^{\circ} 00^{\prime}$ and $31^{\circ} 30^{\prime} \mathrm{N}$ and between Longitudes $29^{\circ} 30^{\prime}$ and $30^{\circ} 30^{\prime} \mathrm{E}$. It situated in two main governorates of Egypt with a total area about $40000 \mathrm{fed}$. About $52 \%$ of the total area lies in the eastern part of Alexandria governorate while $48 \%$ in the western part of El Behira governorate as shown in map (1). The reclamation strategy of this area started at the late of sixties by drying part of Maruit Lake. This reclamation was done in three stages; the third one named Abis extension and covered about 8000 fed.

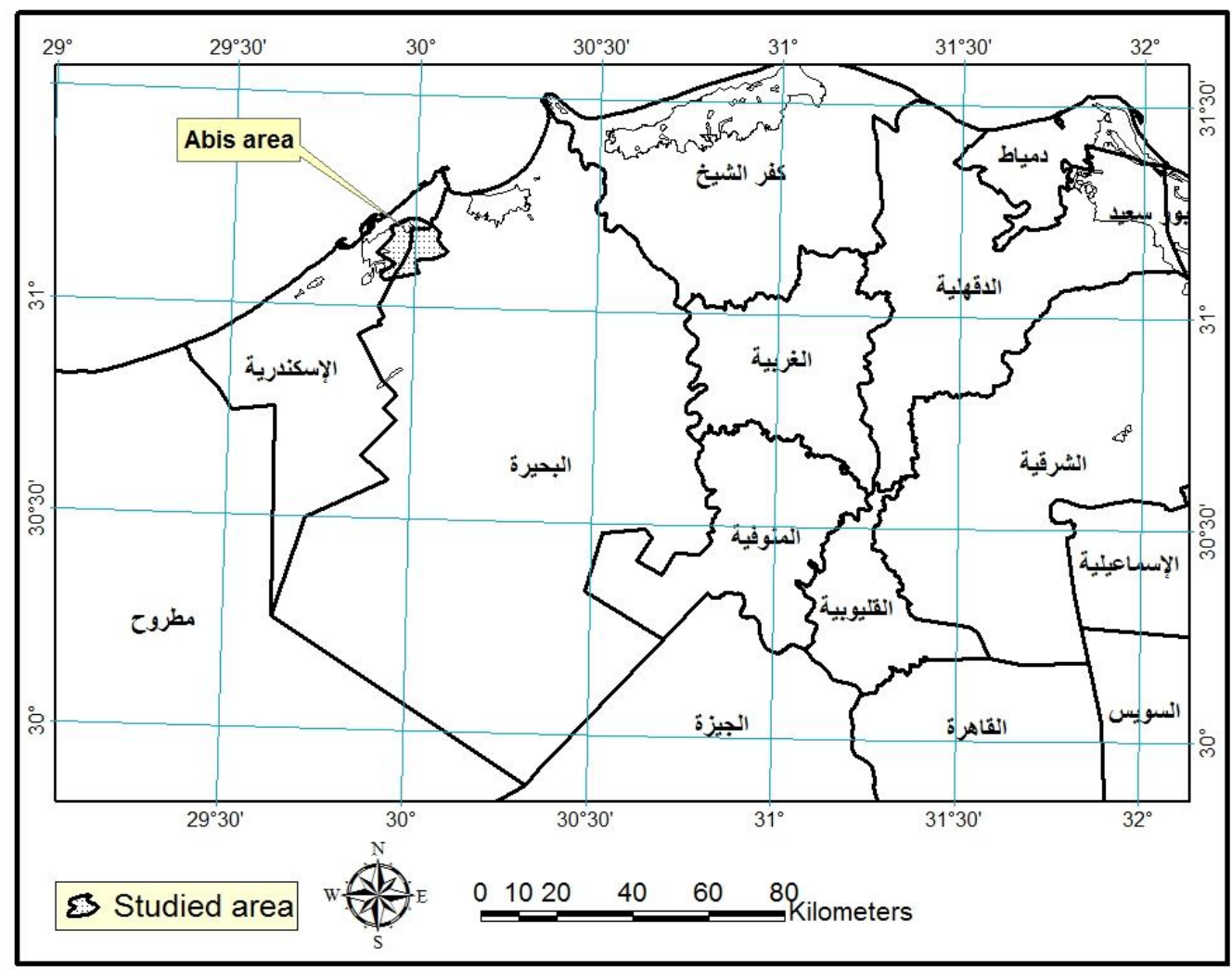

\section{Map 1: General location of the study area}

The study area is characterized by Mediterranean climate with relatively cold and rainy winter and hot and dry summer. Table (1) shows the climatic data for the studied area which obtained from Central Laboratory for Agriculture Climate (2006).

The studied area is covered by Holocene formations (Said, 1962). The soil of this area was derived from the lacustrine deposits of Mariut Lake with an elevation of about $2.5 \mathrm{~m}$ below sea level with almost flat surface.

The main source of irrigation water in the studied area is the Mahmodia canal and the surface irrigation system is used for irrigation. The drainage system is tile drains with moderate efficiency. 
The cropping pattern in the studied area involves the plantation of field crops, vegetables and fodder in addition to minor areas of fruit trees. The main field crops in the area are maize and peanut in summer and fababean and wheat in winter season. The dominant fodders are maize and alfalfa in summer and clover and barley in winter season. The main vegetables in summer season are watermelon, tomatoes and eggplant, while onion, potatoes and squash are considered the main vegetables in winter season. The dominant fruits are grapes, oranges, banana and guava.

Table 1: Meteorological data of Alexandria Region (2006)*

\begin{tabular}{|c|c|c|c|c|c|c|c|}
\hline \multirow[t]{2}{*}{ Month } & \multicolumn{3}{|c|}{ Temperature, ${ }^{\circ} \mathrm{C}$} & \multirow{2}{*}{$\begin{array}{l}\text { Relative } \\
\text { Humidity }\end{array}$} & \multirow{2}{*}{$\begin{array}{l}\text { wind } \\
\text { Sp. } \\
\mathrm{m} / \mathrm{sec}\end{array}$} & \multirow{2}{*}{$\begin{array}{l}\text { Total } \\
\text { rain } \\
(\mathrm{mm})\end{array}$} & \multirow{2}{*}{$\begin{array}{c}\text { ETP } \\
\text { (mm/day) }\end{array}$} \\
\hline & Max & Min. & Average & & & & \\
\hline January & 18.4 & 9.1 & 13.5 & 70 & 3.96 & 54.9 & 2.2 \\
\hline February & 19.3 & 9.3 & 14.1 & 68 & 3.96 & 26.6 & 2.6 \\
\hline March & 21.3 & 10.8 & 15.8 & 65 & 4.12 & 12.9 & 3.4 \\
\hline April & 23.5 & 13.1 & 18.3 & 65 & 3.85 & 4.2 & 4.1 \\
\hline May & 26.6 & 16.4 & 21.2 & 67 & 3.59 & 1.5 & 4.9 \\
\hline June & 28.6 & 20.2 & 24.3 & 69 & 3.59 & 0.0 & 5.7 \\
\hline July & 29.7 & 22.0 & 25.9 & 72 & 3.91 & 0.0 & 5.8 \\
\hline August & 30.6 & 22.7 & 26.5 & 71 & 3.59 & 0.3 & 5.5 \\
\hline September & 29.6 & 21.1 & 25.6 & 68 & 3.27 & 1.0 & 4.9 \\
\hline October & 27.6 & 17.6 & 22.5 & 68 & 2.80 & 9.3 & 3.7 \\
\hline November & 24.2 & 14.4 & 19.1 & 69 & 3.06 & 33.1 & 2.7 \\
\hline December & 20.3 & 10.8 & 15.2 & 70 & 3.69 & 55.6 & 2.3 \\
\hline
\end{tabular}

${ }^{*}$ Central Laboratory for Agriculture Climate

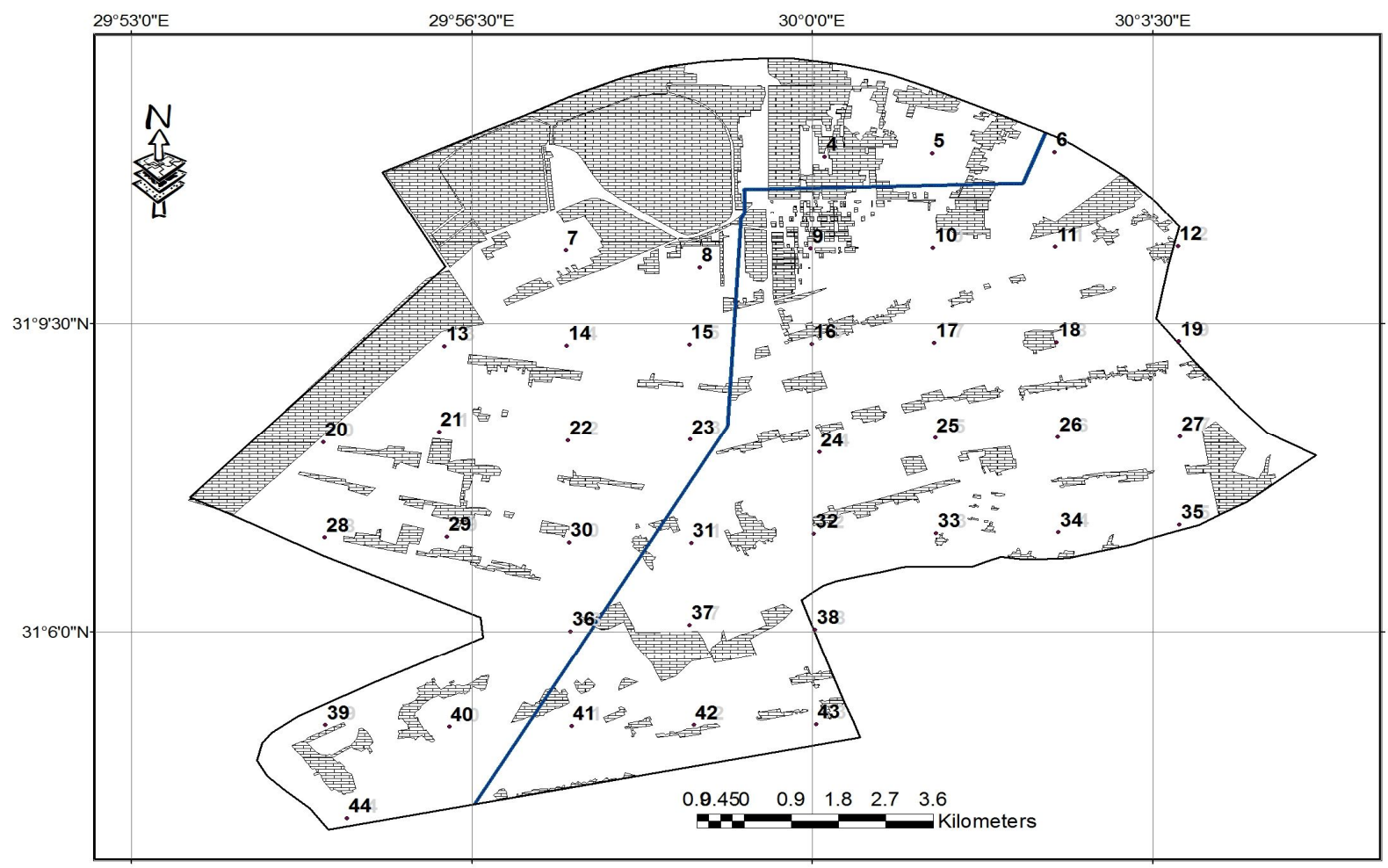

Map 2: Soil profiles location of the study area 


\section{Fieldwork:}

Forty one soil profiles representing the study area were dug as shown in map (2). The soil profiles were described in the field according to FAO (2006). Soil samples were collected from the subsequent horizons according to morphological variations. Water table samples were collected from some profiles to characterize their chemical properties.

\section{Laboratory analysis:}

The collected soil samples were prepared to determine the electric conductivity in $\mathrm{dS} / \mathrm{m}$ and soluble cations and anions in saturation soil extract and soil reaction $(\mathrm{pH})$ in 1:2.5 suspension (Page et al., 1982). Sodium adsorption ratio (SAR) was calculated according to Richards (1954). In addition, total carbonates were determined by Collin's calcimeter. Hydrometer method (FAO, 1970) was used for the determination of silt and clay fractions, while wet sieving was used for very fine sand fractions. The chemical characterizations of water table samples were determined according to Page et al. (1982).

Soil erodibility factor (K):

Soil erodibility factor $(\mathrm{K})$ represents both the susceptibility of soil to erosion and the rate of runoff. It is estimated by the equation of Wischmeier and Smith (1978) as follows:

$$
\mathrm{K}=2.1^{*} 10^{-6}(12-\mathrm{OM})\left(\mathrm{M}^{1.14}\right)+0.0325^{*}(\mathrm{~S}-2)+0.025^{*}(\mathrm{P}-3)
$$

Where: $O M=$ organic matter content $M=(v$. $f$.sand + silt) (100- clay) $S=$ structure index, which is coded as follows:-
(1) Very fine granular.
(2) Fine granular.
(3) Medium to coarse granular.
(4) Blocky, platy, or massive.

$\mathrm{P}=$ permeability class, which is coded as follows:-
(1) Rapid (Kh 50-16 cm/hr)
(2) Rapid to Moderate (Kh $16-5 \mathrm{~cm} / \mathrm{hr}$ )
(3) Moderate $(\mathrm{Kh} 5-1.5 \mathrm{~cm} / \mathrm{hr})$
(4) Moderate to slow ( Kh $1.5-0.5 \mathrm{~cm} / \mathrm{hr}$ )
(5) Slow (Kh 0.5-0.16 cm/hr)
(6) Very slow $(\mathrm{Kh}<0.16 \mathrm{~cm} / \mathrm{hr})$

Soil erodibility classified into three classes as follows:
(i) non erodible $(<0.10)$
(ii) moderately erodible (0.1-0.25)
(iii) sever erodible $(0.25-0.40)$

\section{Wind erosivity factor (C):}

Wind erosivity factor $(\mathrm{C})$ refers to the effect of plants, soil cover, soil biomass, and soil disturbing activities on wind erosion. It was calculated using the equation adopted by FAO (1978):

$$
C=V^{3} / 100 *(P E T-P / P E T)^{*} n
$$

Where: $V=$ mean monthly wind speed at $2 \mathrm{~m}$ height $(\mathrm{m} / \mathrm{sec})$

$\mathrm{P}=$ precipitation $(\mathrm{mm} /$ day $) \quad \mathrm{PET}=$ potential evapotranspiration $(\mathrm{mm} /$ day $)$

$\mathrm{n}=$ number of days in month

\section{Rainfall erosivity factor (R):}

Rainfall erosivity factor is the average of annual summation values in a normal year's rain. It is calculated by the equation of Fournier (1960) as follows:

$$
\mathrm{R}=\mathrm{P}_{\mathrm{m}}{ }^{2} / \mathrm{P}
$$

where: $P_{m}=$ mean monthly rainfall $(\mathrm{mm}) \quad P=$ mean annual rainfall $(\mathrm{mm})$

Assessment of Land capability using ALES software: 
Land capability was calculated by application of Agricultural Land Evaluation System for arid region (ALES-Arid) as described by Abdel Kawy et al. (2004). In this system, six soil classes (Table 2) were introduced, where four factors (soil properties, environmental conditions, soil fertility and irrigation water quality) were taken into consideration. Each factor is described as an index value to give its status in the percentage form. These indices are calculated using some empirical equations. The final index of land evaluation (F.I.L.E) was calculated according to the following equation:

$$
\text { F.I.L.E }=\frac{4}{\frac{1}{(S . I)}+\frac{1}{(E . I)}+\frac{1}{(W . I)}+\frac{1}{(F . I)}}
$$

Where: S.I: soil index

E.I: Environmental index

W.I: Water index

F.I: Fertility index

Table 2: Land capability classes and ratings according to Storie (1964)

\begin{tabular}{ccc}
\hline Class & Degree of Capability & Final value\% \\
\hline $\mathrm{C}_{1}$ & Excellent & $100-80$ \\
$\mathrm{C}_{2}$ & Good & $79-60$ \\
$\mathrm{C}_{3}$ & Fair (Moderate) & $59-40$ \\
$\mathrm{C}_{4}$ & Poor (Marginal) & $39-20$ \\
$\mathrm{C}_{5}$ & Very poor & $19-10$ \\
$\mathrm{C}_{6}$ & Non-agricultural & $<10$ \\
\hline
\end{tabular}

\section{RESULTS AND DISCUSSION \\ Soil characteristics:}

Tables ( 3 and 4 ) show minimum, maximum and average values of main chemical and physical properties and soil erodibility factor " $K$ " in the surface and subsurface horizons of the studied area. The data shows that the studied soils are characterized by sandy loam to sandy clay loam texture in most profiles, while, some profiles have a sandy clay texture. Concerning the surface horizons, data in Table (3) reveal that sand, silt and clay contents vary from 47.80 to $82.50 \%, 2.8$ to $16.5 \%$ and 12.5 to $44.0 \%$ respectively. Data of total soluble salts, as expressed by the electrical conductivity (dS/m), and exchangeable sodium percentage (ESP) indicate that most of the studied soils are characterized by their moderate to high EC and ESP values as shown in Table (3). The EC values ranged between 0.77 and $10.12 \mathrm{dS} / \mathrm{m}$, ESP values being in the range of 1.73 to 18.26 . $\mathrm{pH}$ values ranged between 7.51 and 8.33 , total carbonate content differ between 2.0 and $34.0 \%$. Regarding the subsurface horizons data in Table (4) show that, corresponding values were 47.7 to $80.7 \%, 2.8$ to $27.5 \%$, and 13.7 to $44.1 \%$ for sand, silt and clay respectively, while it vary from 0.83 to $13.86 \mathrm{dS} / \mathrm{m}$ for EC, 1.02 to 36.32 for ESP, 7.66 to 8.46 for $\mathrm{pH}$ and 1.0 to $46.0 \%$ for total carbonate. The high content of soluble salts of these soils may be attributed to the saline nature of their parent material, while the high $\mathrm{CaCO}_{3}$ content is due to the frequent occurrence of shells. The results also, show that the water table depth ranged from $25 \mathrm{~cm}$ to $120 \mathrm{~cm}$ with mean value of about $79 \mathrm{~cm}$. The coefficient of variation (C.V.) of the soil depth (0.40) shows that the soil depth was low homogeneity in the study area. For the surface layer the coefficient of variation show that $\mathrm{pH}$ and SP\%, 
were high homogeneity $(\mathrm{CV}=0.04$ and 0.16 respectively). The lowest homogeneity properties were for $\mathrm{Ca}$ and $\mathrm{Cl}(\mathrm{CV}=0.92$ and 0.94 respectively) and for $E C(C V=0.69)$ as shown in table (3). In the subsurface samples the result shows that the high homogeneity was found for $\mathrm{pH}$ and $\mathrm{SP} \%(\mathrm{CV}=0.02$ and 0.17 respectively) as in the surface layer. While, the highest values of coefficient of variation (C.V.) accordingly lowest homogeneity were found for $\mathrm{Na}$ and $\mathrm{Cl}(\mathrm{CV}=0.91$ and 0.98 respectively) as shown in table (4).

Table 3: The main the statistical parameters of soil characteristics and Erodibility Factor K) for the surface samples

\begin{tabular}{lcccccccc}
\hline & Min. & Max. & Range & Medi. & Mean & S.D. & Var. & C.V \\
\hline soil o & 25.00 & 120.00 & 95.00 & 75.00 & 79.13 & 31.60 & 998.57 & 0.40 \\
depth,cm & & & & & & & & \\
$\mathrm{SP}, \%$ & 43.30 & 95.00 & 51.70 & 73.30 & 73.26 & 11.93 & 142.30 & 0.16 \\
$\mathrm{pH}$ & 7.51 & 8.83 & 1.32 & 8.18 & 8.17 & 0.32 & 0.11 & 0.04 \\
$\mathrm{EC}, \mathrm{dS} / \mathrm{m}$ & 0.77 & 10.91 & 10.14 & 2.81 & 3.32 & 2.28 & 5.19 & 0.69 \\
$\mathrm{Ca}, \mathrm{meq} / \mathrm{L}$ & 1.00 & 34.00 & 33.00 & 5.00 & 7.44 & 6.83 & 46.64 & 0.92 \\
$\mathrm{Mg}, \mathrm{meq} / \mathrm{L}$ & 1.00 & 31.00 & 30.00 & 6.00 & 9.43 & 7.70 & 59.23 & 0.82 \\
$\mathrm{Na}, \mathrm{meq} / \mathrm{L}$ & 4.00 & 80.00 & 76.00 & 19.00 & 23.18 & 18.85 & 355.40 & 0.81 \\
$\mathrm{~K}, \mathrm{meq} / \mathrm{L}$ & 0.12 & 1.20 & 1.08 & 0.40 & 0.46 & 0.28 & 0.08 & 0.61 \\
$\mathrm{HCO}, \mathrm{meq} / \mathrm{L}$ & 1.00 & 10.00 & 9.00 & 2.50 & 3.66 & 2.80 & 7.84 & 0.77 \\
$\mathrm{Cl}, \mathrm{meq} / \mathrm{L}$ & 3.00 & 101.50 & 98.50 & 17.50 & 21.07 & 19.80 & 391.95 & 0.94 \\
$\mathrm{SO}, \mathrm{meq} / \mathrm{L}$ & 0.30 & 56.66 & 56.36 & 13.66 & 15.57 & 13.62 & 185.46 & 0.87 \\
$\mathrm{ESP}$ & 1.73 & 18.26 & 16.53 & 8.12 & 8.74 & 4.90 & 24.04 & 0.56 \\
$\mathrm{CaCO}, \%$ & 2.00 & 34.00 & 32.00 & 18.50 & 15.60 & 9.90 & 98.00 & 0.64 \\
O.M.\% & 0.45 & 1.82 & 1.37 & 0.36 & 0.52 & 0.48 & 0.23 & 0.92 \\
Sand\% & 47.8 & 82.50 & 34.70 & 72.55 & 68.59 & 9.78 & 95.73 & 0.14 \\
V.F. sand\% & 6.10 & 31.59 & 25.49 & 13.58 & 15.38 & 8.03 & 64.55 & 0.52 \\
Silt\% & 2.80 & 16.500 & 13.70 & 8.20 & 8.81 & 3.10 & 9.60 & 0.35 \\
Clay\% & 12.50 & 44.00 & 31.50 & 19.25 & 22.61 & 8.44 & 71.16 & 0.37 \\
Erodibility(K & 0.088 & 0.112 & 0.024 & 0.099 & 0.100 & 0.006 & 0.001 & 0.061 \\
\hline S.D=Standar devition
\end{tabular}

S.D $=$ Standard deviation, C.V=Coefficient of variation=Standard deviation/Mean, var. $=$ variance

Table 4: Soil characteristics and the main statistical parameters for the subsurface samples

\begin{tabular}{|c|c|c|c|c|c|c|c|c|}
\hline & Min. & Max. & Range & Medi. & Mean & S.D. & Var. & C.V \\
\hline SP, \% & 49.95 & 98.00 & 48.05 & 72.05 & 73.23 & 12.13 & 147.12 & 0.17 \\
\hline $\mathrm{pH}$ & 7.66 & 8.46 & 0.80 & 8.02 & 8.02 & 0.17 & 0.03 & 0.02 \\
\hline $\mathrm{EC}, \mathrm{dS} / \mathrm{m}$ & 0.83 & 13.86 & 13.03 & 3.0 & 3.77 & 2.69 & 7.24 & 0.71 \\
\hline $\mathrm{Ca}, \mathrm{r}$ & & & & & 7.2 & & & .85 \\
\hline $\mathrm{Mg}$ & & 30.50 & 28. & 7.75 & 10.58 & 7.85 & 61. & 0.74 \\
\hline $\mathrm{Na}, \mathrm{I}$ & 2.85 & 131.50 & 128.65 & 17.00 & 26.28 & 23.97 & 574.75 & 0.91 \\
\hline $\mathrm{K}, \mathrm{m}$ & & 1.33 & 1.2 & .47 & 0.52 & 0.2 & 0.08 & 0.55 \\
\hline $\mathrm{HCO}_{3}, \mathrm{meq} / \mathrm{L}$ & 1.00 & 6.00 & 5.00 & 2.50 & 2.71 & 1.53 & 2.33 & 0.56 \\
\hline $\mathrm{Cl}, \mathrm{meq} / \mathrm{L}$ & 4.50 & 123.50 & 119.00 & 14.75 & 20.95 & 20.54 & 421.79 & 0.98 \\
\hline $\mathrm{SO}_{4}, \mathrm{meq} / \mathrm{L}$ & 2.58 & 7.60 & 5.03 & 14.97 & 21.51 & 19.02 & 361.82 & 0.8 \\
\hline ESP & & 36.32 & 35.21 & 7.69 & 8.75 & 6.23 & 38.86 & $0.7^{\prime}$ \\
\hline $\mathrm{CaCO}_{3}, \%$ & 1.00 & 46.00 & 45.00 & 18.50 & 16.85 & 12.54 & 157.20 & 0.74 \\
\hline O.M.\% & 0.29 & 0.62 & 0.33 & 0.32 & 0.39 & 0.30 & 0.65 & 0.76 \\
\hline
\end{tabular}




\begin{tabular}{lcccccccc} 
Sand\% & 47.70 & 80.70 & 33.00 & 69.70 & 67.82 & 7.33 & 53.66 & 0.11 \\
V.F. sand\% & 6.00 & 28.56 & 22.56 & 11.38 & 14.25 & 7.13 & 42.36 & 0.50 \\
Silt\% & 2.80 & 27.50 & 24.70 & 11.00 & 11.66 & 4.90 & 23.98 & 0.42 \\
Clay\% & 13.70 & 44.10 & 30.40 & 19.20 & 20.52 & 6.82 & 46.56 & 0.33 \\
\hline
\end{tabular}

Water table analysis:

Data in table (5) shows the values of some chemical properties of water table collected from the studied profiles at Abis region. These data indicate that the $\mathrm{EC}_{\mathrm{w}}$ and SAR vary from 1.19 to 35.80 and from 3.16 to 47.18 respectively, while the $\mathrm{pH}$ values ranged between 7.76 and 8.49 .

Table 5: Some chemical properties for the water table in the study area

\begin{tabular}{cccccccccccc}
\hline P. & $\mathrm{EC}_{\mathrm{w}}$ & \multicolumn{4}{c}{ Cations $(\mathrm{meq} / \mathrm{L})$} & \multicolumn{7}{c}{ Anions $(\mathrm{meq} / \mathrm{L})$} & & $\mathrm{SAR}$ \\
$\mathrm{No}$. & $\mathrm{dS} / \mathrm{m}$ & $\mathrm{pH}$ & $\mathrm{Ca}$ & $\mathrm{Mg}$ & $\mathrm{Na}$ & $\mathrm{K}$ & $\mathrm{CO}_{3}$ & $\mathrm{HCO}_{3}$ & $\mathrm{Cl}$ & $\mathrm{SO}_{4}$ & \\
\hline 4 & 12.81 & 7.85 & 12.5 & 37.5 & 86.0 & 1.3 & 4.0 & 6.0 & 117.5 & 9.8 & 17.2 \\
6 & 5.74 & 7.88 & 6.0 & 16.0 & 44.0 & 1.2 & 5.0 & 5.0 & 15.0 & 12.2 & 13.3 \\
7 & 6.24 & 8.04 & 3.0 & 22.0 & 40.0 & 0.4 & 5.0 & 5.0 & 51.0 & 4.4 & 11.3 \\
8 & 3.89 & 8.27 & 6.0 & 11.0 & 28.0 & 0.9 & 2.0 & 3.0 & 40.0 & 0.9 & 9.6 \\
9 & 5.31 & 7.86 & 5.0 & 11.0 & 37.0 & 1.0 & 2.0 & 8.0 & 41.5 & 2.5 & 13.1 \\
10 & 1.99 & 8.46 & 2.0 & 5.0 & 16.0 & 0.6 & 3.0 & 8.0 & 9.0 & 3.6 & 8.6 \\
11 & 35.80 & 8.23 & 18.0 & 74.0 & 320 & 3.8 & 6.0 & 7.0 & 387 & 15.8 & 47.2 \\
12 & 7.70 & 8.08 & 12.0 & 38.0 & 41.0 & 1.2 & 0.0 & 3.0 & 55.0 & 34.2 & 8.2 \\
13 & 3.21 & 7.91 & 5.0 & 8.0 & 25.0 & 0.10 & 3.0 & 2.0 & 22.5 & 11.6 & 9.8 \\
14 & 1.86 & 7.93 & 7.0 & 2.0 & 12.8 & 0.2 & 0.0 & 3.0 & 11.0 & 7.9 & 6.0 \\
15 & 1.19 & 8.37 & 2.0 & 5.0 & 6.0 & 0.2 & 2.0 & 3.0 & 6.5 & 1.7 & 3.2 \\
19 & 2.56 & 8.49 & 3.5 & 9.0 & 25.0 & 0.4 & 0.0 & 3.0 & 17.0 & 17.9 & 10.0 \\
20 & 5.94 & 7.91 & 12.0 & 23.0 & 36.0 & 0.3 & 2.0 & 2.0 & 28.5 & 38.8 & 8.6 \\
22 & 2.56 & 7.79 & 8.0 & 12.0 & 10.0 & 0.1 & 0.0 & 2.0 & 8.5 & 19.6 & 3.2 \\
29 & 1.66 & 8.17 & 2.0 & 8.0 & 8.0 & 0.7 & 0.0 & 2.0 & 8.0 & 8.7 & 3.6 \\
31 & 6.17 & 8.01 & 12.0 & 18.0 & 43.0 & 0.5 & 0.0 & 4.0 & 33.5 & 35.6 & 11.1 \\
36 & 8.27 & 7.91 & 20.0 & 22.0 & 43.0 & 0.2 & 0.0 & 4.0 & 41.5 & 39.7 & 9.4 \\
38 & 4.11 & 7.83 & 8.0 & 10.0 & 25.0 & 0.6 & 0.0 & 3.0 & 25.0 & 15.6 & 8.3 \\
40 & 5.63 & 8.00 & 12.0 & 16.0 & 24.0 & 0.5 & 0.0 & 3.0 & 33.5 & 15.9 & 6.4 \\
42 & 4.55 & 7.76 & 4.0 & 16.0 & 27.5 & 0.5 & 1.0 & 1.0 & 27.5 & 18.5 & 8.7 \\
\hline
\end{tabular}

Soil Erodibility Factor (K):

Table (3) show summary of statistical parameter for soil erodibility factor "K" in the studied soil. The values of soil erodibility factors "K" ranged between $0.088-0.112$. Most of the studied profiles belong to class 2 which represent soils that are moderate erodible ( $\mathrm{K}$ values ranged between 0.1 and 0.25 ), while some of the studied profiles belong to class 1 which represent soils that non erodible ( $\mathrm{K}$ values < 0.1 ). The coefficient of variation $(\mathrm{C} . \mathrm{V}$.) of the soil erodibility factor "K" was 0.061 which reflect high homogeneity in the study area.

Relation between soil erodibility factor and soil properties:

Regarding the correlation coefficients matrix between soil erodibility factor and soil properties are given in Table (6). The K- values are strongly positively correlated with silt content $(r=0.68)$. Soils having high silt content are the most erodible one. They are easily detached; tend to crust and produce high rates of runoff (Wischmeier et al., 1971). The positive correlation of $\mathrm{K}$ with silt values are in agreement with those of Wischmeier and Mannering (1969), Romkens et al. (1977), and El-Menshawy et al. (2005), but disagree with findings of El-Asswad and Abufaied (1994) and El-Menshawy et al. (1997). 
Data in table (6) also shows that the K- values are positively correlated with very fine sand content $(r=0.48)$ which agree with findings of Wischmeier et al. (1971) Romkens et al. (1977), Wischmeier and Smith (1978), Kukal et al. (1991) and El Menshawy et al. (1997). The positive correlation of K values with silt and very fine sand data are attributed to the easiness of detaching of these particles in comparison with clay and to their transferability in comparison with the coarser particles. The $\mathrm{K}$ - values have moderate positive correlation with sand percent $(r=0.33)$. These results are in agreement with those obtained by Wischmeier et al. (1971), Wischmeier and Smith (1978), Kukal et al. (1991) and El Menshawy et al. (1997).

In contrast the $\mathrm{K}$ values are negatively correlated with clay content ( $r=$ 0.51 ) and this may be attributed to the hardness of detaching of these particles due to aggregation. Also, the $\mathrm{K}$ values have low negative correlation with \% $\mathrm{CaCO}_{3}(r=0.21)$ this may be attributed to the presence of calcium carbonate as of cementing materials for soil particles which reduce the susceptibility of the soil to detachment. Also, the $\mathrm{K}$ - values were negatively moderate correlated with percent of organic matter $(r=0.31)$ since increasing organic matter improves the permeability of soil surface and decreases runoff. Also organic matter and clay act as cohesion factors and resist erodibility (Wischmeier and Mannering, 1969). These results are in accordance with those obtained by Meyer and Harmon (1984) and El-Asswad and Abufaied (1994). Generally, No significant correlation was found between $\mathrm{K}$ values and $\mathrm{pH}$, EC or ESP values.

The above discussions indicated that the soil becomes less erodible with the decrease in silt fraction, regardless of the corresponding increase in the sand fraction or the clay fraction. However, percentages of silt, clay and sand must be considered in relation to other physical and chemical properties.

Table 6: Correlation matrix of different soil properties in the study area

\begin{tabular}{lcccccccccc}
\hline & $\mathrm{pH}$ & $\mathrm{EC}_{\mathrm{e}}$ & $\mathrm{ESP}$ & $\mathrm{CaCO}_{3}$ & $\mathrm{O} . \mathrm{M}$ & VFS. & Sand & Silt & Clay & $\mathrm{K}$ \\
\hline $\mathrm{pH}$ & 1.00 & & & & & & & & & \\
$\mathrm{EC}_{\mathrm{e}}$ & -0.20 & 1.00 & & & & & & & & \\
$\mathrm{ESP}$ & 0.10 & 0.69 & 1.00 & & & & & & & \\
$\mathrm{CaCO}_{3}$ & -0.13 & -0.06 & 0.04 & 1.00 & & & & & & \\
O.M & 0.18 & -0.43 & -0.43 & -0.58 & 1.00 & & & & & \\
V.F.S. & 0.22 & 0.22 & 0.41 & -0.08 & -0.25 & 1.00 & & & & \\
Clay & 0.26 & -0.25 & -0.28 & 0.17 & -0.51 & 0.56 & 1.00 & & & \\
Silt & 0.05 & -0.20 & -0.10 & 0.04 & 0.64 & -0.4 & 0.29 & 1.0 & & \\
Sand & -0.24 & 0.28 & 0.05 & -0.16 & 0.06 & -0.4 & -0.95 & -0.6 & 1.00 & \\
K & -0.17 & 0.01 & -0.06 & -0.21 & -0.31 & 0.48 & 0.33 & 0.68 & -0.51 & 1.0 \\
\hline
\end{tabular}

\section{Wind Erosivity Factor "C":}

Wind erosivity factor $(C)$ varies greatly with location because it affects by soil cover, soil biomass, and soil disturbing activities as well as velocity of wind. The $\mathrm{C}$ monthly values in the studied areas ranged between 3.33 and 18.28 as shown in Table (7). The annual value of $C$ was 134.5 , this relatively high value may be attributed to that the increasing of wind velocity in this area as shown in table (7). The highest values were observed in March through August, this may be due to the absence of rainfall in these months. El-Menshawy et al. (2005) studied the wind erosivity factor in some soils of southeast El-Manzala Lake and 
reported that the total value of $\mathrm{C}$ was 127.05 , this relatively high value may be attributed to that most of these soils are non cultivated.

\section{Rainfall Erosivity Factor (R):}

Table (7) shows the variability of rainfall erosivity factor "R" throughout 2006 season. The annual rainfall erosivity factor "R" for the studied area is low (41.035) due to the relative dry climate. The monthly rainfall erosivity factor "R" is related to the amount of received rain for each month. Approximately 90 percent of the erosivity occurs in the months of January, February, November and December in the studied area. The highest values were in January (15.11) and December (15.50), whereas the lowest values appeared in June, July and August.

\begin{tabular}{lcc}
$\begin{array}{l}\text { Table 7: wind erosivity factor }(\mathbf{C}) \text { and rainfall erosivity } \\
\text { factor }(\mathbf{R}) \text { of the studied area }\end{array}$ \\
\hline Month & $\mathrm{C}$ & $\mathrm{R}$ \\
\hline January & 3.637 & 15.115 \\
February & 11.808 & 3.548 \\
March & 18.283 & 0.835 \\
April & 16.571 & 0.088 \\
May & 13.726 & 0.011 \\
June & 13.868 & 0.000 \\
July & 17.872 & 0.000 \\
August & 13.843 & 0.000 \\
September & 10.440 & 0.005 \\
October & 6.034 & 0.434 \\
November & 5.089 & 5.495 \\
December & 3.331 & 15.503 \\
total & 134.500 & 41.035 \\
\hline
\end{tabular}

\section{Land evaluation and land use planning Land capability classes:}

The ALES Model (Agricultural Land Evalution System) provides prediction for general land use capability for a broad series of possible uses (Abdel Kawy et al., 2004). Evaluation results from the application of ALES model on the study area indicate that the capability of most area belongs to Class 2, which means soils are good for agriculture, regardless to the existing management practices. Only $\mathrm{C} 2 \mathrm{aw}, \mathrm{kh}$ and $\mathrm{C} 2 \mathrm{aw}$ are the land capability subclasses which recognized in the study area which indicates that the main limiting factors are available water and/or hydraulic conductivity. Limited areas belong to class 3 which reflects fair or moderate capability. This class (C3) divided to four land capability subclasses. These Subclasses are C3 aw, ece; C3 aw, kh, sd; C3 aw, sd and C3 aw, sd, ece with available water (aw), hydraulic conductivity (kh), soil depth (sd) and soil salinity (ece) as limiting factor.

\section{Soil suitability classes for specific uses:}

The ALES model was used to predict soil suitability for some common crops cultivated in the study area including: wheat, maize, alfalfa, cabbage, 
cotton, fababean, onion, pea, rice, sorghum, tomato and watermelon. Data of soil suitability class and subclasses are presented in Table (8). These data indicate that most of the studied soils are suitable (class 2) for wheat, maize, cabbage, cotton, fababean, pea, sorghum, tomato, watermelon. Some of the studied soils are highly suitable (class 1 ) for alfalfa, onion and rice, regardless to the existing management practices. However, limited areas belong to class 3 which reflect moderately degree of soil suitability or class 4 which reflect weak or marginal degree of soil suitability for some of the traditional tested crops. Regarding the subclasses, data show that the main limiting soil properties in most of the studied soils are hydraulic conductivity (kh), salinity (ece), saturation percent (sp), soil depth (sd) and exchangeable sodium percent (esp) as shown in Table (8).

Table 8: Soil suitability classes for each crop of some selected profiles in the study area

\begin{tabular}{ccccccc}
\hline p. No & wheat & maize & alfalfa & fababean & onion & pea \\
\hline 5 & S2 t kh & S2 & S2 kh & S2 & S2 & S2 \\
7 & S2t kh & S2 kh & S2 kh & S3 ece & S3 ece kh & S3 ece \\
10 & S2 & S2kh & S2 kh & S2 & S2 & S2 \\
14 & S2t kh & S2 & S2 kh & S2 & S2 kh & S2 \\
17 & S2 & S2 kh & S1 & S3 kh & S1 & S2 kh \\
22 & S2t kh & S2 & S2 kh & S2 & S2 kh & S2 \\
25 & S2 & S2 kh & S1 & S3 kh & S1 & S2 kh \\
29 & S2 t kh & S2 & S2 kh & S2 & S2 kh & S2 \\
34 & S1 & S2kh & S1 & S2 kh & S1 & S2 kh \\
37 & S2 & S2kh & S1 & S4 sd kh & S2 & S2 \\
40 & S2t kh & S3 ece sp & S2 kh & S4 ece esp & S4 ece kh & S4 ece \\
42 & S2 & S2 kh & S1 & S4 sd kh & S2 & S2 \\
\hline
\end{tabular}

Table 8: Cont.

\begin{tabular}{ccccccc}
\hline p. No & rice & cotton & sorghum & watermel. & cabbage & tomato \\
\hline 5 & $\mathrm{~S} 2 \mathrm{t}$ & $\mathrm{S} 2 \mathrm{sd}$ & $\mathrm{S} 2$ & $\mathrm{~S} 2$ & $\mathrm{~S} 2$ & $\mathrm{~S} 2$ \\
7 & $\mathrm{~S} 2 \mathrm{t}$ & $\mathrm{S} 4 \mathrm{sd}$ & $\mathrm{S} 2$ & $\mathrm{~S} 2$ & $\mathrm{~S} 2$ & $\mathrm{~S} 2$ \\
10 & $\mathrm{~S} 2 \mathrm{t}$ & $\mathrm{S} 2 \mathrm{sd}$ & $\mathrm{S} 2$ & $\mathrm{~S} 1$ & $\mathrm{~S} 1$ & $\mathrm{~S} 2$ \\
14 & $\mathrm{~S} 2 \mathrm{t}$ & $\mathrm{S} 2 \mathrm{sd}$ & $\mathrm{S} 2$ & $\mathrm{~S} 2$ & $\mathrm{~S} 2$ & $\mathrm{~S} 2$ \\
17 & $\mathrm{~S} 1$ & $\mathrm{~S} 2 \mathrm{sd} \mathrm{kh}$ & $\mathrm{S} 2 \mathrm{kh}$ & $\mathrm{S} 2 \mathrm{kh}$ & $\mathrm{S} 2 \mathrm{kh}$ & $\mathrm{S} 2 \mathrm{kh}$ \\
22 & $\mathrm{~S} 2 \mathrm{t}$ & $\mathrm{S} 2 \mathrm{sd}$ & $\mathrm{S} 2$ & $\mathrm{~S} 2$ & $\mathrm{~S} 2$ & $\mathrm{~S} 2$ \\
25 & $\mathrm{~S} 1$ & $\mathrm{~S} 2 \mathrm{sd} \mathrm{kh}$ & $\mathrm{S} 2 \mathrm{kh}$ & $\mathrm{S} 2 \mathrm{kh}$ & $\mathrm{S} 2 \mathrm{kh}$ & $\mathrm{S} 2 \mathrm{kh}$ \\
29 & $\mathrm{~S} 2 \mathrm{t}$ & $\mathrm{S} 2 \mathrm{sd}$ & $\mathrm{S} 2$ & $\mathrm{~S} 2 \mathrm{kh}$ & $\mathrm{S} 2$ & $\mathrm{~S} 2$ \\
34 & $\mathrm{~S} 1$ & $\mathrm{~S} 2 \mathrm{kh}$ & $\mathrm{S} 2 \mathrm{kh}$ & $\mathrm{S} 1 \mathrm{kh}$ & $\mathrm{S} 2 \mathrm{kh}$ & $\mathrm{S} 2 \mathrm{kh}$ \\
37 & $\mathrm{~S} 1$ & $\mathrm{~S} 2 \mathrm{kh}$ & $\mathrm{S} 2 \mathrm{kh}$ & $\mathrm{S} 2 \mathrm{kh}$ & $\mathrm{S} 2 \mathrm{kh}$ & $\mathrm{S} 2 \mathrm{kh}$ \\
40 & $\mathrm{~S} 3$ ece t kh & $\mathrm{S} 4 \mathrm{sd}$ & $\mathrm{S} 3$ esp & $\mathrm{S} 3$ ece esp & $\mathrm{S} 3 \mathrm{esp}$ & $\mathrm{S} 3 \mathrm{esp}$ \\
42 & $\mathrm{~S} 1$ & $\mathrm{~S} 2 \mathrm{kh}$ & $\mathrm{S} 2 \mathrm{kh}$ & $\mathrm{S} 2 \mathrm{kh}$ & $\mathrm{S} 2 \mathrm{kh}$ & $\mathrm{S} 2 \mathrm{kh}$ \\
\hline
\end{tabular}

\section{REFERENCES}

Abd El-Kawy O.R., H.A. Ismail, J.K. Rod and A.S. Suliman. 2004. A developed GIS-based land evaluation model for agricultural land 
suitability assessments in arid and semi arid regions. Res. J. of Agric. and Biological Sci., 6 (5): 589-599.

Abd El-Rahman, M.A., M.A. Husain, M.A. Waab, R.R. Ali and E.F. Abd ElSalam. 2009. Physiographic and soil mapping of the soils to El-Manzala Lake by using Remote Sensing And GIS.Egy. J. of Soil Sci. 49 (3): 389408.

Bahr, H. and T. Vogtle. 1999. GIS for Environmental Monitoring. Stuttgart: E. Schweizerbart'sche Verlagsbuchhandlung.

Bahnassy, M. 1992. Application of Geographic Information Systems for analyzing wadi El-Haraka watershed, Northwest Coast, Egypt. Unpublished Ph. D. thesis. University of Alexandria.

Beasley, R.P., J.M. Gregory and T.R. McCarty. 1984. Erosion and sediment pollution control.The lowa State University Press, Ames., lowa.

Darwish, A.M. A. 1977. The morphological and chemical properties of Alexandria University farm..M.Sc. Thesis, Fac.Agric., Univ.of Alexandria.

El-Asswad, R.M. and A.F. Abufaied. 1994. The erodibility of three Libvan soil types in relation to their physical and chemical properties. J. of arid envir., 26:129-134.

El-Attar, H. and H.M. Bakr. 1963. Reclamation of saline alkaline soils by leaching Abis area. Dipl.Thesis. Inst. of land Recl., Univ. of Alex.

El-Attar, H., S.M. Abd El-Rahman, Y. S. Kassem, and F. H. Morgan. 1987. The spotted crop of soils of El-Nahda project. Egypt. J. Soil Sci. 27 (4); 397-408.

El-Fayoumy, M.E. 1989. New approach of land evaluation of some Egyptian regions. Ph.D. Thesis. Fac. Of Agric., Univ. of Alexandria.

El-Hassanin, A.S., M.T. Labib and E.I. Gaber. 2002. Rainfall erosivity and soil erodibility as related to water erosion in Burundi. Egypt J.Soil Sci. 42:185-199.

El-Hussieny, N., Y. S., Kassem, E.M., El-Zahaby. 1985. Micromorphology of som soils developed in the lacustrine deposits of Lake Mariut, Egypt. Communication in Science Development Research. 10 (93):57-72.

El-Husseiny, N., Y.S. Kassem and S.M.H. Abd El-Rahman. 1988. Morphology genesis and classification of El-Bosaily soils. Desert instit. Ball., A.R.E., 38:97-114.

El-Menshawy, A., M. Bahnassy, and A.F. Saad. 1997. Predicting soil erodibility in relation to its physical and chemical properties for some Egyptian soils. Alx.Sci. Exch. Vol.18 No3, pp. 353-363.

El-Menshawy, A. B., R. I. Fayed and H.I. El-Attar. 2005. Characterization, Classification and Land Evaluation of Some Soils Southeast El-Manzala Lake, Egypt. Alex. Sci. Exch., 26 (3): 306-314.

El-Nahal, M.A., Sh. Abdel-Aal, A.A. Abd El-Wahed and I. Raafat. 1977. Soil studies on the Nile Delta Egypt. J. Soil Sci. 17 (1): 66-75.

El-Zahaby, E.M., M.H. Bahnassy, A.M. El-Saadani and R.I. Fayed. 1999. 
Chemical and mineralogical properties and spatial variability of soils under different environments of deposition, southeast Mariut Lake. Alex. J. Agric. Res., 44 (3): 71-85.

FAO. 1970. Physical and chemical methods of soil and water analysis. Soils Bulletein No. 10, FAO, Rome.

FAO. 1976. A framework for land evaluation. FAO Soils Bull.55.

FAO. 1978. Methodology for assessing soil degradation. Report on the FAO/VNGP export consultation, FAO. Rome.

FAO. 1985. Guidelines: Land evaluation for irrigated agriculture. Soil Bulletin

55, 212 pp, FAO, Roma.

FAO. 2006. Guidelines for Soil Description. FAO, Rome.

Fayed, R.I. and A.B. El Menshawy. 2006. Land Capability and EconomicSuitability of EL-Oruba Village Soils, Egypt. Alex. J. Agric. Res., 51 (1): 105-112.

Fayed, R. I. 2011. Soil Quality Changes as Influenced by Land Use Periodsand Irrigation Water Quality in Egyptian lacustrine soils. J. Agric. Sci. Monofya Univ, 36 (4): 1099-1116.

Fournier, F. 1960. Climate et erosion. Press Univ. de France, Paris.

Gomez, J. A., P. Romero, J. V.Giraldez and E. Fereres. 2004. Experimental assessment of runoff and soil erosion in an olive grove in a Vertic soil in southern Spain as affected by soil management. Soill Use and Management, 20: 426-451.

Kukal, S.S, H.S. Sur and S.S. Gil. 1991. Factors responsible for soil erosion hazard in sub montane Punjab, India. Soil use and Mang. 7.1.38-44.

Labib,F. and C.C Sys. 1970. Soils on lacustrine and marine deposits in United Arab Republic. Pedologie, 20, 381.

Meyer, L.D. and W.C. Harmon. 1984. Susceptibility of agricultural soils to interill erosion. Soil sci. soc. Am. J., 48: 1152-1156.

Mahmoud, M.A.S. 1978. Distribution of some micronutrients in some alluvial, lacustrine, fluvio-lacustrinse and calcareous soils of Egypt as related to the soil genesis. M.Sc. Thesis, Fac. Agric., Univ. Alexandria.

Mansour, A.M. 1979. An approach to land evaluation rural purpose of some alluvial soils of gypt. M. Sc. thesis, Fac, of Agric. Cairo Univ.

Morgan, F.N. 1976. The spotted pattern of Al-Nahda project .M. Sc. Thesis, Fac. Agric., Univ. Alexandria.

Morgan, R. P. 1996. Soil erosion and conservation. Second Edition. LongmanGroup Ltd.

Nikkami, D., M. Elektorowicz, and G. Mehuys. 2002. Optimizing the management of soil erosion. Water Quality Resource Journal of Canada, 37(3): 577-586.

Omar, M.A. and O. A. El-Kolie. 1970. Optimum allocation of agricultural inputs to soils with variable productivities. Tropical and Subtropical Inst., Liebsig, Germany.

Page, A. L.; R. H. Miller and R. Keeny. 1982. Methods of Soil Analysis. $2^{\text {nd }}$ ed Agron. Monograph, No. 9. ASA, Madison, USA.

Richards, R.L. (ed.) 1954. Diagnosis and improvement of saline and alkali soils. Agriculture Hand Book No. 60, U.S Govt. Printing Office, Washington, USA. 
Romkens, M.J.M., C.B. Roth and D.W. Nelson. 1977. Erodibility of selected clay subsoils in relation to physical and chemical properties, Soil Sci. Soc. Am. J., 41:954-960.

Said, R. 1962. The Geology of Egypt. Elsevier Puplishing Co. Amesterdam. Storie, R.E. 1964. Handbook of soil evaluation. Associated Students Store. U. Cal. Berkeley, CA.

Sys, C. and W. Verheye. 1974. Land evaluation for irrigation of arid regions by the parametric method, Trans. 10 th Intern. Soil Congr., Moscow, 10:155.

Sys, C., E. Van and J. Debaveye. 1993. Part 1 and II. Methods in Lan Evaluation. Agric. Pub. No. 7, GADC, Brussels, Belgium , 247p

Wild, A. 1996. Soils and the environment. An introduction. Cambridge University Press.

Wischmeier, W.H. and J.V. Mannering. 1969. Relation of soil properties to its erodibility. Soil Science Society of Amer. Proc., 33: 131-137.

Wischmeier, W.H., C.B. Johonson and B.V. Cross. 1971. A soil erodibility monograph for farmland and co nstraction sites. Journal of soil Water conservation, 26; 189-193.

Wischmeier, W.H., and D.D. Smith. 1978. Predicting rainfall erosion losses: a guide to conservation planning. U.S. Department of Agriculyure Handbook 537.

\section{الملخص العريي}

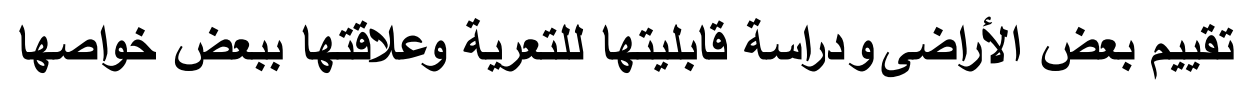

فى المناطق الواقعة شمال غرب دلتا التيل

$$
\begin{aligned}
& \text { د/ رجب إسماعيل فايا } \\
& \text { معمل بحوث الأراضى الملحية والقلوية بالإسكندرية-معهد بحوث الأراضيو المياه والبيئة- مركز البحوث } \\
& \text { الزراعية- مصر }
\end{aligned}
$$

يهدف هذا البحث الى دراسة خصائص الأرض، حساب معامل الانجراف الأرضي (K)و التعرف على الخصائص

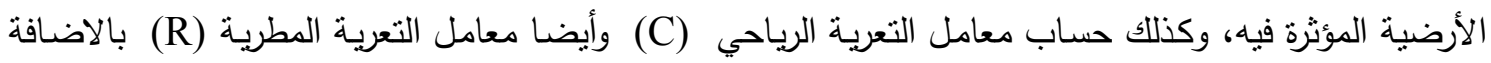

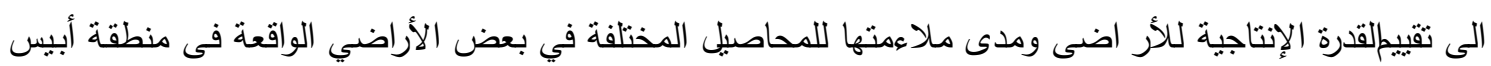
جنوب بحيرة مريوط. تم حفر إع قطاع أرضي لتمثل منطقة الدراسة، وقد تم وصف كل القطاعات مورفولوجيا.

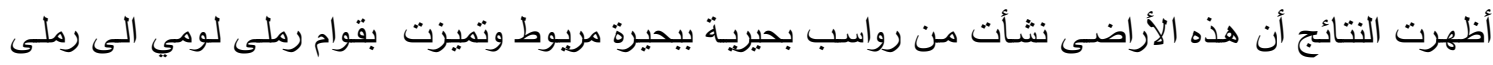

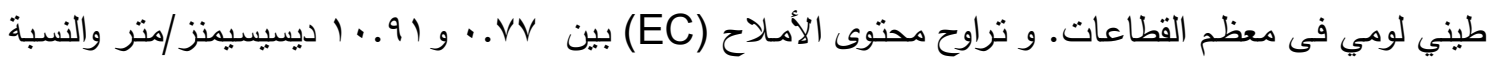

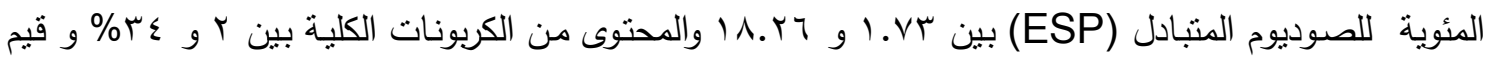

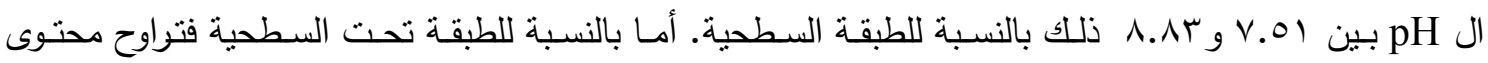

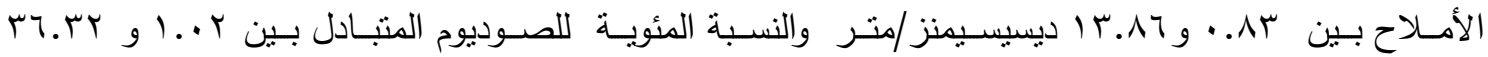




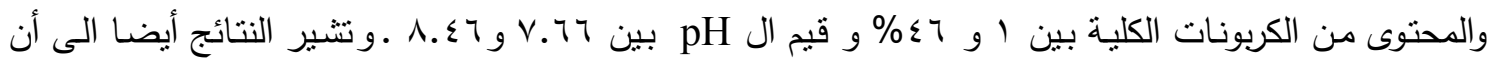

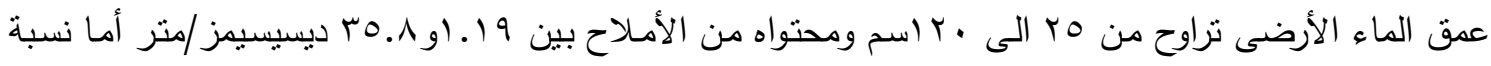

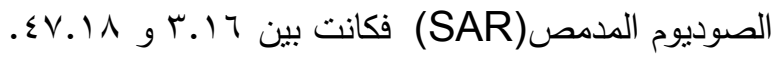

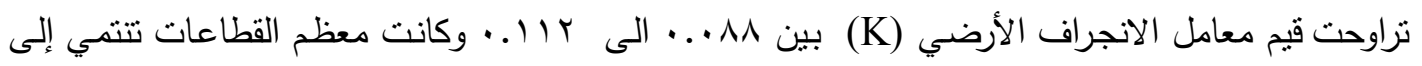

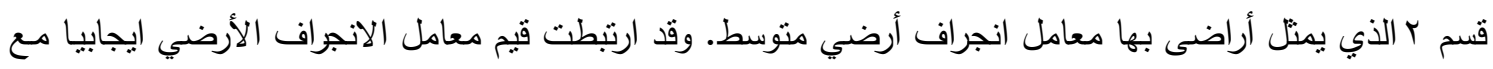

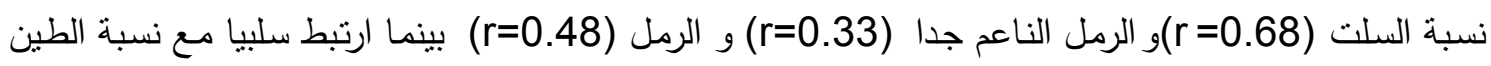

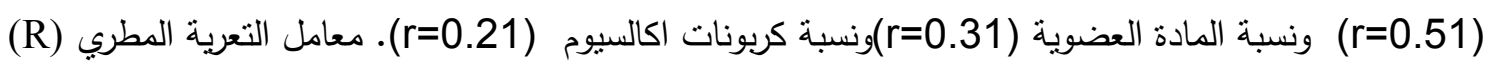
منخفض (. . (₹) بسبب المناخ الجاف نسبيا حيث يتوقف على كميات المطر الثـهري. و نراوحت قيم معامل

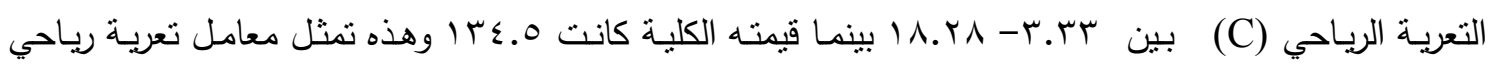
مرتفع وذلك لزيادة سرعة الرياح فى هذه المنطقة لقربها من البحر ـ أظهرت نتائج تطبيق برنامج التقبيم

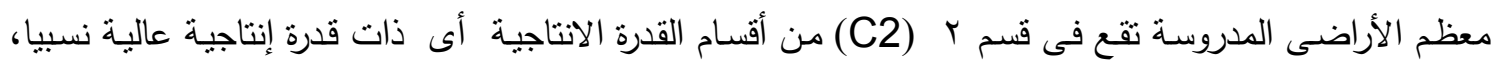

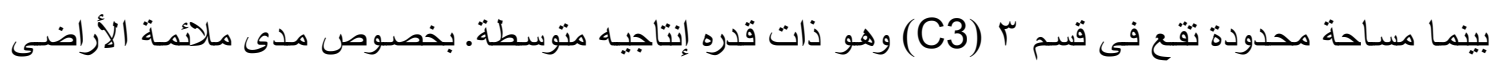

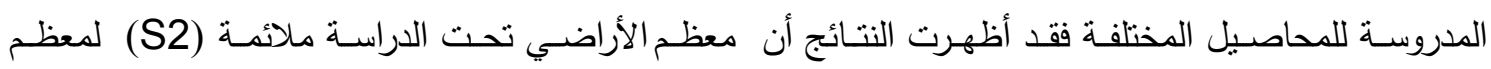
المحاصيل و بعض منها ذات ملائمة عالية (S1) بينما قليل منها ذات ملائمة متوسطة الى ضعيفة (S3, S4)

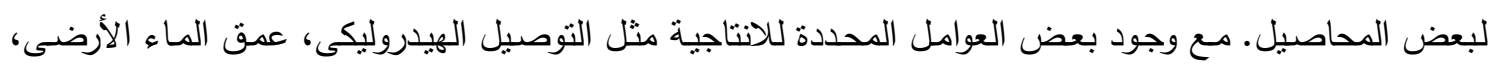
الملوحة (EC) ونسبة الصوديوم المتبادل (ESP). 